\title{
The Values of Moral Learning in "Ketika Cinta Bertasbih" Novel Written by Habiburrahman El Shirazy
}

\author{
Received: $05^{\text {th }}$ April2016; Revised:06 ${ }^{\text {th }}$ April2016; Accepted: $19^{\text {th }}$ July 2016
}

Permalink/DOI: http://dx.doi.org/10.15548/jt.v23i2.167

\section{Mulyadi}

Institut Agama Islam Negeri Imam Bonjol

Padang, West Sumatra, Indonesia

Email: ajo.mulyadi@yahoo.co.id

\begin{abstract}
A novel written by Habiburrahman El Shirazy "Ketika Cinta Bertasbih" (when love is connected to God) is decorated by a variety of ideas, values and ways of life. This novel does not only provide narrative story entertained with Islamic values, but also served as media to form public and readers' morals. Because the story line presented in this novel contained an overview of everyday life containing of moral learning, therefore, it is very interesting to be studied. The current study seeks to uncover: 1) the value of moral learning and value of worship to God' 2) the value of self moral learning. The type of research is Library Research using discourse analysis method (content analysis). It was found out that (1) The moral value of learning to the God contained a message of faith with arguments through the universe. It let worship of God, be grateful and stay away from vanity. (2) The value of self-moral learning included the value patient, persevering, self-authority, high optimistic, responsibility and self-firm.
\end{abstract}

Keywords: Learning, moral learning, value.

How to Cite: Mulyadi. (2016). The values of moral learning in "Ketika Cinta Bertasbih" novel written by Habiburrahman El Shirazy. Al-Ta Lim Journal, 23(2). doi: http://dx.doi.org/10.15548/jt.v23i2.167

\section{INTRODUCTION}

In the concept of transformative learning (Mezirow, 2003), habits of mind, meaning perspectives, and mindsets, should be considered to be more inclusive, discriminating, open, reflective, and emotionally able to change. These fixed assumptions and expectations promote moral learning that emerges in both communicative and instrumental learning. Communicative learning refers to "what someone means when they communicate' and 'the process of understanding involves assessing claims to rightness, sincerity, authenticity, and appropriateness rather than assessing a truth claim'.

The above principles have long existed in novel which is interesting to study. Its presence means to explore the aesthetic values, and is expected to realize universal values prevailing in a society, such as religious values, educational, humanitarian, moral, ethical, and others. The presence of a novel cannot be separated from socio-cultural background of the author's life and ideology, the environment when the creation of the novel and the readers' society who will appreciate the work (Isnaniah \& Hassan, 2013). 
The novel of "Ketika Cinta Bertasbih" (When Love is Connected to God) by Habiburrahman El Shirazy has been studied from different perspectives. (Isnaniah \& Hassan, 2013) put forward eight values including religious values. Elements of Feminism in Islamic movie Isnaniah (2013) further explored the same topic through 'ecranisation' Isnaniah (2015) while Safitri (2010) discovered three main moral values such as religion, education, and social. Different from all the above studies, however, this study focused on moral learning which illuminates the teaching of Islam.

Human beings are naturally in a unique creation. Human beings have the power to lead towards goodness. On the other sides, human beings have the power that leads towards the despicable and reprehensible acts. In other words, human uniqueness lies in the dualism derived from the inherent character as the consideration in behaved. Therefore, the factors that lead a person in behave are; first, good things, integrative, optimistic, and positive, helping each other, patient. Second, humans have a tendency towards despicable things, negative, disintegrative, rough. This situation is a challenge in human life as the defense of the noble and admirable character.

Etymologically, moral is derived from the Arabic in the plural form. "Al-Khulq" is singular form of moral (ahklak) which means habit, temperament, character, obedience. (Tono, Sularno, Mujiono, \& Triyanto, 1998). Behavior becoming a habit arises from human self-intension. Moral within the meaning of this word is mentioned in Allah's decree as a gift for Prophet Muhammad as a form of delegation to become the Apostle of Allah (Abdullah, 2007) As the Qur'an QS. AlQalam (68): 4.

Moral is often associated with ethical (Djatnika, Rahmat, 1985). Ethics and moral are derived from Greek words meaning habit. While character (budi pekerti) in Indonesian definition is a compound word of mind (budi) and character (pekerti). Budi is derived from Sanskrit, which means conscious, and character (pekerti) comes from Indonesia itself, which means behavior (Tono et al., 1998). While the moral comes from Latin "mores" is the plural of mos, which means custom and culture. In Indonesian General Dictionary moral is good or bad of action and behavior.

Novel is defined as fiction work, miroe terms of roman that contains implicit parts and the values of life (Goleman, 2006) In terms of its' value, Supriadi (2006) said that the existence of the religious based novel become more popular. It has been proven this theme color the variety of the contemporary novel in Indonesia. Furthermore, most of them contain moral massages. In brief, novel of Ayat-Ayat Cinta provides the lesson that is related to Islamic religion which is possible to be used as the learning models. He added that the Islamic novel present the stories about the life of human that may lead to a recall that we are the servant of Allah, the stories are mixed with the Islamic value, shows the good deeds and the values of truth to the esthetic contain by using the a great language.

Bertens (1993) said that the word ethic comes from the Greek, ethos in the singular and it has variety of meanings: the usual residence, meadows, stables, habits, customs, morals, character, feelings, attitudes, and ways of thinking. In the plural form (ta etha), it means custom. It is explained in Encyclopedia that ethics is the philosophy of values, decency on both bad and good. While common dictionary explained that ethics is part of a philosophy that teaches magnanimity. According to Imam Al-Ghazali in his book "Ihya Ulumuddin" the changes to a person's character is possible, for example, rough to the pity. Here imam al-Ghazali confirmed the existence of changes in conditions of some of God's creation. But what is the ordinance of God as the sky and the stars. While in other circumstances such 
as in self-personal can be completed through educational process. Eliminating the lust and anger is not possible to minimize both really become possible through some spiritual practice (Bahreij, Hussein, n.d.).

From the above explanation it is found that among moral, ethic and behaviour have similarities and differences. The similarity is in determining the regulation and human behavior. While the difference lies in it measurement based on the Qur'an and Hadits. Ethic is determined from the main and behavior in ones daily life. It can be concluded that moral is knowledge concerning the spiritual and physical behavior of human beings.

Suraida (2010) concludes that in its "descriptive" sense, morality refers to personal or cultural values, codes of conduct or social mores that distinguish between right and wrong in the human society. Describing morality in this way does not make a claim about what is objectively right or wrong, but only referring to what is considered right or wrong by people. Moral development is organized gradually. It is developed in accordance with the development of one's soul. Human beings are born equal both in spirit and character. But, teaching and learning is able to distinguish between them.

Al-Ahmad, Abdul Aziz son of Abdullah explained that the factors that make up a personality can be classified into two parts: (a) heredity is a factor that arises from self individual. So who derived is not the nature which has grown by environmental influences, but the legacy behavior, parents' behaviour and proficiency, both physical and spiritual. (b) environmental factors is factors arising from the socio-cultural environment (ahmad, 2006). One of the key factors in forming the personality or behavior is the environment. Environment is a factor that affects a person since the beginning of his growth.

Environment has a huge influence on the growth and development of a human. Besides, an investigator must be sensitive to environmental factors besides heredity. The neighborhood is divided into three fields such as (1) Family environment, (2) school environment, and (3) Society Environment (Yusuf, 1982).

The purpose of moral learning in Islam is to establish human morality, polite in both talking and acting, nice behavior, wise character, polite, sincere, honest (Thaib, 1984). In other words, this learning aims to build up human virtue character ( $\mathrm{Al}$ Fadhillah). Based on this purpose, moral teaching development can be established through the time, circumstances, lessons and activities. While Omar M. M Al-Toumy AlSyabany stated that the purpose of morality is to create happiness of the world and the hereafter. The perfection of the individual and happiness are progress, strength and determination of society. (AsySyaibani, 1979).

It can be concluded that, principally, the purpose of morality is to achieve happiness and harmony in worshiping Allah and to build harmony between creature and environment. Besides, its purpose is to establish human high prestige and perfect as well as over other creatures. Moral learning values is particularly important as moral learning is a source of human happiness, a source of Legislation relating to social issues, laws, customs, and norms. Hence, the education in the form of Moral development perceived to be more important than just building physical prosperity. Therefore, the development of physical will be barricade for the happiness of the human soul itself. (Kaswardi, 1993).

In family environment, parents can provide education and exemplary, both in the form of modesty in speaking and behaving. While in the community, it needs an institution for moral guidance including written messages. Moral learning can also be initiated through stories or readings containing admirable values. (Fudayana, 2006). Moral learning can be presented through variety of instructional media. One of them is novel. Novel is a literary work 
containing values, ideas and motivations or doctrines expressed in the form of a story (narrative). Novel tells various problems of human life and human interaction with the environment and human relationship with God. It is the result of dialogue, contemplation and reactions to the environment and the life of the author (Nurgiyantoro, 2000). Thus, novel as a media has message that full of values, including the value of moral learning. The novel that meets this character is "Ketika Cinta Bertasbih".

Ketika Cinta Bertasbih written by Habiburrahman El Shirazy tells a man with full persistence, independence, determination and spirit of struggle to actualize his dreams Al-Azhar University, Egypt. The author packed his novel with imaginative language, detail, and simple, and he consider the quality of the content. The story and dialogue is full of positive value and full of moral learning to his readers. This novel is a religious theme, in which lies moral values that make readers increased their independence, struggle and faith. Indirectly it is embedded admirable moral values. This novel contains religious values that can enlighten the soul, enables the readers to adopt moral values presented in the novel.

The principle of my life is based on Islam, because I'm assured with the teachings of Islam. Among the teachings of Islam which I believe is the teaching of self sanctity maintaining. The sanctity guarded by Islam is the sanctity of the relationship between men and women. Islam does not allow contiguity between men and women unless it is a legitimate couple (Shirazy, 2008).

This novel can be used as a vehicle for fostering morals learning or the nurturing of moral learning values, students and the community, both in storyline presented, as well as the character played in the themes displayed, so it needs to be studied the moral learning values contained in the novel. Although the novel is usually seen as a means of entertainment and pastime, but ideally novel is one of the media that can provide a positive influence on their readers, which occurs indirectly and sometimes not recognized by the reader

What are the values of morality learning contained in the novel Ketika Cinta Bertasbih written by Habiburrahman El Shirazy? To answer it, it is disclosed of how the morality learning values toward Allah, how learning values against themselves, and how those moral learning values against Muslims fellow written in the novel.

\section{METHOD}

Descriptive analysis will provide description of the words contained in the novel. As well as explaining the meaning of a sentence, that is the value of moral education in Ketika Cinta Bertasbih novel. Discourse approach was used in this study to focus on the interpretation of meaning written in words, text, symbols of art such as paintings, novels, poems etc. This is in line with Mezirow (2003) who stated that discourse refers to dialogue involving the assessment of beliefs, feelings, and values (Mezirow, 2003). The primary data source was the data that delivers direct first hand data (Surakhmad, 1994). the primary data as well as the object of this study is novel Ketika Cinta Bertasbih written by Habiburrahman El Shirazy Meanwhile, Secondary data sources are data obtained and considered as benchmark study (Soekanto, 1982). Secondary source in this study is a work that serves as a primary source of support resources such as books and other relevant literature.

Basically, content analysis in the field of literature attempts to understand literary works from extrinsic aspect. The aspects surrounding the outside of the structure of aesthetic is investigated, understood and discussed in detail. The meaning in the content analysis is generally symbolic. So the work of content analysis is to reveal the subtle 
symbolic meaning in literature. Content analysis is an analysis that meet five requirements: (1) The text systematically processed by using a theory that has been designed previously; (2) The existing text to look for units of analysis and categorized according to the theory of reference; (3) The analysis process should be able to contribute to the understanding of the material; (4) The analysis process based on the description; (5) analysis is conducted qualitatively (Endraswara, 2003).

The steps in analyzing this novel revealed describing all data associated with the issue such as words, phrases, clauses, sentences, and paragraphs, as well as images, and the results in the form of excerpts from the data set with actions, thoughts, views of life, concepts, ideas, ideas presented through its works. Then, classifying and grouping the data in accordance with the existing problems. Finally, the data were analyzed and interpreted to be concluded.

\section{RESULT AND DISCUSSION}

The value of moral learning to God is an attitude and a description of human behavior towards his Creator. How humans behave and act to God in this vast earth? how humans understand the creation of the universe which is too beautiful and balanced to serve as evidence of the existence of God, or can someone took a perfect natural as proof that Allah is Perfect?. Thus, in order to bring a strong conviction of the existence of God. Human need to pay attention to his creation and then a strong belief that human life will be reflected in both attitude and behavior toward God. As a quote page 45 below states that:

"How merciful lord is, who beat the ocean in such a way so that I passed the ships contain a human. In fact, probably among human who were on ships that there are human beings who are very disobedient to God. After all that, God still showed His mercy (Habiburrahman El Shirazy,
2008, 45). If it is noticed, the character named Azzam in the novel states that love of God to the universe enjoyed by human never faded even though humans often act of disobedience to Him.

To convince the reader about the omnipotence of God, Habiburrahman provide rational arguments with the existence, balanced and beauty of the universe. This argument is expected that the reader is able to realize and understand the mistake of confidence to the almighty of God in creating the universe. Modern life through now sometimes makes the barrier to forget his Lord. Human put world as their destination; in fact the Hereafter is the ultimate goal. Thus, modern life would be expected to increase human faith to their lord. Habiburrahman explained the argument about human doubts about the sovereignty of God in the creation of this vast universe.

If God is more than one, it could have been the division of tasks. There is a charge of creating the sun, there is a charge of creating the earth, and there is a charge of creating the heavens and beyond. If so, they are not God Almighty. Because the division of tasks was to show weakness, they showed omnipotence. The true God is the God Who created the universe and master exciting (Habiburrahman El Shirazy, 2008).

The above quotation indicates that a strong argument about the singularity (Oneness) of God in the creation of the universe. Had the creator of more than one then there was a division of labor, which in turn shows the weakness of the Creator? Thus, the man expected to have a thorough understanding of the true faith by observing the unity of the Creator of His omnipotence. Nature created by God which aim to meet all human needs. So that later the man is able to give thanks and good behavior towards Allah manifested through the behavior of worship. 
The evidence of the faith through worship of God is as a manifestation of his ingratitude. As evidence of human gratitude to God, it is certainly a wide variety of rules that God gives. Its rule is worship. As the quote page 79 as follows:

"Azzam woke up twenty minutes before the dawn call to prayer rang out. ... After that he took holy water. He remembered not pray Witir yet. Then he prayed witir (Habiburrahman El Shirazy, 2008).

The excerpt of pages 271 as follows: Azzam realizes it is already four and a half and he had not the night prayer yet. He had heard from a scholar that night prayers can remove the anxiety and bring serenity. He wanted to pray a few cycles it. (Shirazy, 2008).

In his bow, he asked Allah to give additional powers to study and be given additional useful knowledge to him. He amplifies' Azzam to graduate that year. And he would study it with full concentration (Shirazy, 2008).

Worship in human life beside the obligation is a sign of gratitude for all blessing. Implementation of worship basically aims to humans and there is no advantage for the Lord. God does not have the desire to take advantage of His creatures. God hold the heavens, the earth, and its contents in no need of His creatures. Precisely, human beings are in the need of the Lord. God is Rich and Merciful. Allah gave huge possible freedom to His creatures to choose to do good or evil. All have consequent. Fair, there is no injustice. One will receive the Good results in accordance with what he planted over the years.

Habiburrahman convey religious value to the reader how people should act and behave in God in all things. In the message implied that, there is Moral learning value to
God, which is evidenced through worship. The value invites the reader to practice their religion in any condition. Then quote page 140 as follows:

... Cut Mala and her friends doing the dawn prayer in congregation, they held a prayer rug in the living room. Who became a priest that morning is Cut Rica. After they pray then they remember Allah. Then read alMa'tsurat. After that they returned to their rooms to recitations (Shirazy, 2008).

The above quote, Habiburrahman wants to show the reader that not only the prayers at the mosque or in Mushalla but in the house can also be done. Implementation of the obligatory prayers in congregation is done as a sign of gratitude to God. It means that the message contains a moral lesson, by inviting readers to always worship Allah in congregation. Then on page 154 he stressed again that Anna, the figure of a devout student and always be thankful to his Lord. This fact was found in a citation contained in page 154 as follows:

Her eyes were wet, "Rabbana
taqabbal minna innaka antas
samii'ul'aliim". God accept our
charity, that you are the greatest
listener and know all things. "Softly
to himself, as he prays with all soul
that there is no higher achievement
than the receipt of pious charity by
God and rewarded with the blessing.
(Shirazy, 2008).

The above quotation explains that Anna is a student of al-Azhar, praying to God 'through the deepest soul. It invites the reader to pray to God with a heart in prayer so it delivered to be acceptable to God. Anna, not only beautiful and intelligent student, but also the daughter of a respectable religious leader who always remain grateful of all the favors 
received. All the favors she received did not make him arrogant and haughty towards anyone. The message, Habiburrahman been doing social criticism to the modern society that tends individualist, haughty and arrogant and demeaning others human relations are no longer on sincerity but based on the interests.

Human should be patient in any way. In Indonesian Dictionary, it is defined bear with ordeal. In terminology, patient is an endure attitude or restraint on the difficulties he faced the most appropriate definition is the attitude that begins with endeavor, and ends with the blessing and sincere. The patient in a variety of circumstances remains calm, always remember God. Patience is a part of main character required of a Muslim. The concept of patient can be seen in the Qur'an Surat Al-Baqarah verse 155-156.

Patient lies in Azzam, when he was abandoned by his father. His father died while he was still at the University of al-Azhar in Cairo, Egypt. Since then, Azzam become independent and become the father of his family. But he remained steadfast to keep life ahead. As quoted (Shirazy, 2008).

His body had asked for a break. But, he must finish that night. He should not be defeated by his red eyes. He must be patient, disciplined or, the work will accumulate and the result could be a mess ... . but he remained steadfast, patient and complete the work to be completed that night, then everything will be easier.

It shows that how powerful Azzam is. he bears his life with fermented soybean business to find the money to him and his family in Indonesia. It determines the tenacity of azzam since his father died. His fortitude and patience also determine in his attitude, which should he entertained himself for the loss of his father, but he showed fortitude and patience by not showing sadness in others. Azzam could only imagine to meet the mother and younger sister in the village. As already quoted (Shirazy, 2008) the following:
It is Reasonable for someone who had not see his family for years and hope to meet his family. But with a little patience the meeting will be more meaningful because it is not a little patience. He may return. But he was not finished his college and her sisters still require him to work hard.

Likewise Fadhil, a friend of Azzam, has huge heart ordeal, the one he loved is married to his friend (Shirazy, 2008).

Fadhil continues to fight for his soul steadfast because there is no other choice. That afternoon he and several Aceh students went to airport to pick up Zulkifli and his entourage. When he met Zulkifli he bends over backwards to be sincere and happy. He embraced his old friend's happily. He said: Welcome to the land of Moses, $\mathrm{O}$ beloved companions.

The quote above, Allah describes in the Qur'an Surah Al-Baqarah verse 155. Azzam must be steadfast and patient because the real nature of the patient and steadfast in the face of calamity. Because with these characteristic will allow us to be the one who subsided to the decission and regulation of Allah. each person's faith will be tested. Thus, Azzam shows the attitude of steadfast and patient, because it is the power and decission of Allah.

The desire to succeed in life must be done work hard. Islam orders to its followers to strive and work hard as a means to reach the blessing. In this novel the attitude of hard work is shown in Azzam and his friends. They work hard every day before leaving for the campus to support their life. (Shirazy, 2008) the following paragraph:

Since then he feels that he should be more serious about life. He began to develop his skill, not only in business success, but also academic success. He began to organize his study. After that he would study and learn relentless. he intends to defeat 
the circumstances. He did not want the spirit fade away.

It can be understood that Azzam work so hard to complete his study and support his family, he never tired of doing his duty. Azzam hard working is not just to meet the physical needs but to meet the expenses of their school as well. Azzam did not expect the cost of others but he was trying to meet their own needs. Azzam business provides the best for his consumer, best in both price and quality. Not just a concept in the mind or on paper. He remembered method of ancient Chinese, "you'll get what you want, if you work hard before you die" (Shirazy, 2008).

Azzam told his friends that, "The formula of success is very simple, practice and concentration, and improve practices and increase concentration." Then Azzam said, " you were coward Nang, This is business Nang. Business! The business lives is courage Nang. In the business that succeeds are those who understand that there is little difference between the challenges and opportunities, and they can turn it into an advantage. Azzam even aspire with strong determination and hard work, that the minimum of his education is master degree.

He targets at least he obtained his study at least to master degree. but he has one obsession, that he must be rich! $\mathrm{He}$ was already known as a businessman in Cairo, he was not known as an activist group study, he intent to organize respected businessman in Indonesia later $\ldots$ if he was great conglomerate he could strive in the way of Allah with their wealth, just like Utsman bin Affan and Abdur Rahman bin Awf. And he will still try to practice the knowledge gained while studying in Egypt as much as possible (Shirazy, 2008).

From some of the quote above, it appears that Azzam hard work in supporting his life with his friends can be used as an illustration in a difficult life for the reader. In the midst of economic difficulties and opportunities, we must have the spirit of hard work and courage to seek business opportunities that able to gain a huge advantage. Big advantage will still be able to make your business thrive. Moreover, he lives around with big responsibility. Azzam and his friends tried hard and never give up covering the cost of his life and family.

As human being, we must perpetuate self sanctity. In the sanctity of human life must keep themselves ('iffah) perpetuate self sanctity means that the person is able to maintain every member of his pysical and spiritual of disobedience. Azzam tried to explain to Eliana about maintaining herself of sin. Eliana who used to hang freely does not maintain herself especially in association with the man. This was proven when Eliana gave a special prize to Azzam. His encounter with Azzam to impress her, so that he could change her views to be pious woman. It is shown in the page 119 Azzam tried to defend himself when Eliana will offer prizes, as follows:

I have principles. The principle of my life is based on Islam, because I am totally sure with the teachings of Islam. Among the teachings of Islam which I believe is the chastity perpetuate. Physical Sanctity and spiritual purity .... .Among holiness sanctity guarded by Islam is the sanctity of the relationship between men and women (Shirazy, 2008).

It is understood that Azzam firmly and clearly advised Eliana to maintain her personal purity from sin. Eliana again realized her mistake. The following quote on page 121 as follows: she remembered his cousin who lives in remote of Lumajang. Her name is Nurjanah. Since childhood, she always wear a headscarf, the cousin is now a teacher at an Islamic elementary schools ... she does not want to come in contact except with men 
permitted to her. Now she realized the secret. (Shirazy, 2008) Eliana realizes her mistake. She remembered her cousin who wears hijab from her childhood. And has purity of daily attitude.

It is described that personal purity must be maintained and preserved in any condition, especially nowadays with the advancement of culture and the technology that surrounds human life. Lafe is so easy and practice. The world becomes small and barely had not any intermediary, free culture became commonplace. Thus, maintaining the physical and spiritual $s$ in any condition. Here are excerpts of El-Shirazy, (2008) Azzam always prayed that God would keep himself and his sanctity of women and sin, "God keep me from the slander of women," he prayed softly as he sat beside her. Indeed, in addition to the Egyptian girl that he had to sit .

The efforts to keep ourselves from sin sometimes are negligent, Azzam felt when Eliana present in shadow. But Azzam quickly realize his mistake and ask God's forgiveness for his sin. Somewhere suddenly he felt guilty. He felt guilty and disgusted with himself, easily deceived by the external appearance is deceiving. He was disgusted with himself that he felt too hard to maintain his attitude toward women who not permitted to him. Azzam lament his mistake and weakness. He vowed to maintain his faith to be better (Habiburrahman El Shirazy, 2008).

Life should have Faith and Responsibility. Among self morality is belief in something and responsibility in all respects. Both of these characteristic is written in Ketika Cinta Bertasbih. Belief of something is heart activity that emerges from an understanding and calculations to do something, for example, you'll get something. It is revealed from faith of Furqan to marry anna, a solehah student, intelligent and smart, as stated in page 373 :

Furqan very confident to marry Anna, the famous girl among Indonesian student in Cairo, it will definitely be realized. He has been argued that destiny is the laws of nature, it follow cause and effect. He felt he had found the truth of his opinion it through hundreds of events he has experienced over the years. Also the events experienced by others. For example, he always passed the exams because she learned well. Passing the exam is effect, learning is it cause.

The quotation above describes that Furqan is very confident to marry a student named Anna Altafunnisa, the famous student for her friendly, beauty, intelligence among Indonesian student in Cairo. Furqan has been argued that fate is a natural law. He believes that the destiny is order of cause and effect. If he was earnestly trying to get Anna, surely he would have. He felt he had found the truth. Tiara also believes all has been determined by God, here is the quote on page 147, ,... mate in his conviction is chosen, chosen by God. What is done in the early morning of spring is believed to be an effort (ikhtiarnya.) "(Shirazy, 2008).

Tiara believes that everything is given and choosen by Allah. Human has only to try and enable to determine the success. Although during this time she was hoping and trying to get Fadhil becomes his life companion. But his father had chosen for Zulkifli to be her spouse.

Life should be firm and self-sacrifice as a key to the future success. This learning value remains the Muslims to a hadith of Prophet Muhammad, when a Bedouin companions met the prophet and ask about anything that makes enough in her life. Prophet Muhammad says, "let's say that you have faith in god and be strong commitment' it means that life need confidence and then fixed or firm in the establishment, do not be so easily swayed despite the difficulties that befall you. The advice into goodness and selfsacrifice will make the reader intrigued. The following excerpt by (Shirazy, 2008): 
"My son, it would be wonderful if you met any. Whatever you feel; love, grief, blessing, accident, angry, relieved, disappointed, unhappy associated with the hereafter. ... so your heart will be very sensitive to receive the light of wisdom and guidance. Your heart will be soft and gentle ... and as you wrath that you feel sadness, mixed with fear and regret it on your mistakes. That's what you see and how you feel at the time. Then bio it were full". (Shirazy, 2008)

The above quotation shows obstinacy and independence value and willing to accept the calamity. Anna scolded by her mother when she ignored the call. Anna is really sad. She felt all the accomplishments she has achieved gone and ruined, only grief and sorrow because the weakness of her soul. When her father gave advice, that advice is perpetual in her. Her soul is not steady yet. Anna realizes her mistake and intent to improve it and willing to sacrifice for his father and mother. Thus, the value of courage and self-sacrifice in every breath of human life must be raised. Sometimes people neglected a small thing just to achieve big thing.

The difficulty of life and the limitation of activity have a considerable role to make firm establishment of the human soul, tenacious and relentless. This is experienced by Fadhil and her sister, Cut Mala. Hard condition has made Fadhil strong and independent for himself and his sister to complete their study in Cairo. Here's the quote on page 318 :

Abah said that you and me have to study as high as possible. Knowledge is able to increase ones and nation prestige. Actually, I wish to pursue my master in Sudan, or Malaysia. But the cost, you know, we have no such cost. Perhaps I will fight to continue my master in Al-Azhar, while waiting for you to complete your study. " (Shirazy, 2008)

Fadhil and his friends always support Azzam to defend his life and his sister, he could not ask the financial support from his mother. He and his friend helped Azzam make tofu, meatballs to earn money. $\mathrm{He}$ always remembered his father's message to not only finish undergraduate but also graduate level. This proves that Fadhil is independence and self-sacrifice for him and his sister future. It is as a major role performed by Khairul Azzam. Here is the quotation:

God has not allowed me to get married. I still have to pay attention to my brother and sister to the gates of clear and bright future. ... $\mathrm{He}$ immediately thinks of his responsibility as the eldest brother. He cried. He felt how God love him. God still wanted him to focus on his responsibilities to finance his younger siblings. (Habiburrahman El Shirazy, 2008)

".... I never think that you support your brother and sister in indonesia". (Shirazy, 2008)

The quotation above describes that Azzam was simple, creative, able to resolve the problem, dare to take risks, never give up and high-spirited effort student. Where there is a chance to maneuver the business he grabs it no matter high risk, as long as there is a will there is a way. In addition, Azzam is a brother who was very concerned about the mother and his sisters, although he expenses the college to work. Azzam prouds that finally he is able to take his sisters reaches their goals. Husna, his elder sister was the first to become a psychologist and the best national author. Lia's, his second sister completed her study in Elementary School Teacher Education, and 
became a favorite teacher in SDIT Al Kauthar Solo. And her younger sister Sarah, she almost seal the Holy qur'an in Al Qur'an boarding School Qudus. Azzam as a big brother reflects how much affection and sacrifice to her sisters. It can be exemplary for the reader.

Azzam is a creative student, "Let Indonesia people in Cairo know me that I am a student of Al-Azhar who did not pass yet, and more concern in business Tempe, meatballs, and catering." so diligent and industrious, "Maybe Mr khairul'm tired that time. When one tired, some time his emotion is unpredictable. He was working from morning till night. "A responsible man," God has not let me get married. I still have to pay attention to my brother and sister to the gates of clear and bright future ". He immediately thought of his responsibility as the eldest brother. He cried. He felt how big God love to him. God still wants him to focus on his responsibility to finance his younger siblings. ". "I had no idea that you support your brothers and sisters in Indonesia ..." as well as the Independent, "At that time he himself was a very require advent source of fortune to sustain his life, and her sisters. and he focus totally in the business of making meatballs. "

Pious man, "he justifies his actions by thinking that the calling of the azan is ahead of the phone ringing. And he must put that came first. "

Intelligent man, he is the prototype of Indonesian smart, intelligent and unpretentious generation, but he was born from low class family. So, very typical of Indonesia! His intelligence is proven when at the first year in Al-Azhar, he received jayyid Jiddan (special) achievement. And therefore he got a scholarship from the majlis A'la. It is understood that message of self moral education presents the massage of view of life to the readers. People should be patient in all things, the desire to succeed in life must work hard, human must maintain the sanctity of the self ('iffah), he must have confidence and responsibility. And he must also firm establishment and self-sacrifice as the key to future success.

Modern human vanity has made them depressed. Tranquility aspired never be achieved, and the restless spirit of worship are often neglected. Thus, the quote on page 36 as follows:

Since the accidents in the hotel and he (Furqan) realized his mistake, he is getting a lot closer to the Creator of human and the universe. After attaining his master's degree he reinforces his worship. As he want to pay his mistake. Once he was in Dhuha time, he prays twelve cycles (Shirazy, 2008).

The figure of Furqan is a handsome and rich student because he is a son of rich businessmen in Jakarta. He studied in Egypt, living as self-sufficient and insensitive to its environment. One night, he got the most severe ordeal of life so that his future becomes bleak. But he is aware of all these mistake and return to God with a feeling of regret. The message to readers is that in life sometimes human inattentive to God's command, then one should keep coming back to God. This is a learning of moral. When humans had committed a sin then repent immediately and do not further away from God.

when Azzam reminded Eliana of prayer, "Ms. Eliana did you pray?" Said Azzam quietly. ... "Ah prayer is easy! The important thing is this. There is an important task for $\mathrm{Mr}$ Khairul tonight ". (Shirazy, 2008)

From the quote above we know that, Azzam reminded Eliana about the obligation of prayer. Eliana is the son of Ambassador in Egypt who lives in the neighborhood and are highly educated. Eliana considers the implementation of a regular routine of worship only and not be reduced in value if implementation is delayed. Eventhough it is considered normal abandoned. Eliana 
behavior is a reflection of life freely, thus underestimating their religion. Learning value to the reader does not neglect religious duty. Violating the rule of religion means that one does not grateful to God.

Azzam's comment likes "Ok, Beautiful. But if you cannot cover the you body, has no shame, do not wear the hijab, do not love the religious way of life, it's not the girl I dreamed (Shirazy, 2008).

Habiburrahman outline the issues in society with smooth language. The quote above can be determined that the author criticizes the Islamic community who always violates the religion, for example in wearing cloth, have no shame, glamour and etc. They had no religion. Moreover, young people in big cities, are materialistic and freedom. Azzam, a man who always maintain the sanctity and he dreamed a wife in accordance with Islamic criteria. The learning value to readers that beauty is bestowed must be grateful through the implication of Islamic role into daily life. The following quotation:

I also have principles. The principle of my life is based on Islam, because I'm most confident with the teachings of Islam. Among the teachings of Islam which I believe is the chastity. The sanctity of spiritual and physical (....) So that Muslims continue to maintain the sanctity of spiritual and physical. Among the sanctity guarded by Islam is the relationship between man and woman. Islam does not allow intimate contiguity between men and women unless it is a legitimate husband and wife. (Habiburrahman El Shirazy, 2008)

It reminds the readers to maintain personal purity and spiritual as the duty of Muslim. Moreover, the social intercourse is disorganized. Islam is present to organized human life. Habiburrahman convey the meaning to the reader to always keep the character of the Lord by keeping the association although in any condition. Therefore, keep away from the sanctity of the free man woman relationship which is become destructive relationship to God. It is understood that the value to the readers on the issues of moral to the God intended that the reader is able to understand and believe and do a commendable behavior in life. Make the universe as evidence of God's existence because the reason that people neglected the God. Humans should be grateful for what he has received, only God is worthy of worship and do not always be arrogant and cocky on God's earth, and do not underestimate obligations towards Him.

\section{CONCLUSION AND RECOMMENDATION}

Ketika Cinta Bertasbih (When Love Is Connected to God) written by Habiburrahman El Shirazy contains the values of Islamic learning, especially learning of moral values, so that the novel can be categorized into a religious novel and its position can be used as instructional Media, especially moral education. Learning moral values containing in this novel based on the analysis consist of three classifications message. First, the value of learning morals to the God that contains messages to the reader to believe in the arguments of reason in proving to the almighty of God through the universe. The implication of faith is committed through worship for God. As a manifestation of ingratitude towards his evidence, the nature of human arrogance will undermine human faith in daily life.

Second, the value of moral selflearning which contains a message to the reader about life, people should be patient in all cases, the desire to succeed in life must work hard, ('iffah), human must build up confidence and responsibility and must also establish the firm and self-sacrifice as the key to future success. 


\section{REFERENCES}

Abdullah, M. Y. (2007). Studi Akhlak Dalam Perspektif al-Qur'an. Jakarta: Amzah.

Ahmad, A. aziz bin abdullah al. (2006). Kesehatan Jiwa kajian korelatif Pemikiran Ibnu Qoyyim dan Psikologi Modern. Jakarta: Pustaka Azam.

AsySyaibani, O. M. A. T. (1979). Falsafah Pendidikan Islam. Jakarta: Bulan Bintang.

Bahreij, Hussein. (n.d.). Hadits Shahih Bukhari Muslim. Surabaya: CV Karya Utama.

Bertens, K. (1993). Etika. Jakarta: Gramedia.

Djatnika, Rahmat,. (1985). Sistem Ethika Islami (Akhlak Mulia). Surabaya: Pustaka Islam.

Endraswara, S. (2003). Metodologi Penelitian Sastra: Epistemologi, Model Teori Sastra dan Aplikasi. Yogyakarta: Pustaka Widyatama.

Goleman, D. (2006). Emotional intelligence. Bantam.

Habiburrahman El Shirazy. (2008). Ketika Cinta Bertasbih (17th ed.). Jakarta: PT. Gramedia.

Isnaniah, S. (2015). Ketika Cinta Bertasbih Transformasi Novel Ke Film. Jurnal Kawistara, 5(1).

Isnaniah, S., \& Hassan, U. H. A. (2013). The Representation of Islamic Teaching in The Novels by Habiburrahman El Shirazy. Jurnal Pengajian Media Malaysia, 15(1), 119-127.

Kaswardi, E. K. (1993). Pendidikan Nilai Memasuki Tahun 2000. Diterbitkan atas kerjasama Komisi Pendidikan KWI/MNPK dan Penerbit PT
Gramedia Widiasarana Indonesia.Ki Fudayana. (2006). Filsafat Pendidikan Barat dan Filsafat Pendidikan Pancasila: Wawasan Secara Sistematis. Yokyakarta: Amus.

Mezirow, J. (2003). Transformative learning as discourse. Journal of Transformative Education, 1(1), 5863.

Nurgiyantoro, B. (2000). Teori Pengkajian Puisi. Yogyakarta: Gajah Mada University Press.

Safitri, D. (2010). Masalah-masalah Sosial dalam Novel Ketika Cinta Bertasbih Karya Habiburrahman El Shirazy: Tinjauan Sosiologi Sastra. Universitas Muhammadiyah Surakarta.

Soekanto, S. (1982). Kesadaran Hukum dan Kepatuhan Hukum. Jakarta: Rajawali.

Supriadi, A. (2006). Transformasi Nilai-nilai Ajaran Islam dalam Ayat-ayat Cinta Karya Habiburrahman El-Shirazy: Kajian Interteks. program Pascasarjana Universitas Diponegoro.

Suraida, I. (2010). The Analysis of Moral Values of Deasylawaty Prasetyaningtyas's Novel "Hades Sang Autis." Salatiga: State Islamic Studies Institute (STAIN) Salatiga.

Surakhmad, W. (1994). Pengantar penelitian ilmiah. Bandung: Tarsito.

Thaib, I. (1984). Risalah akhlaq. Bina Usaha.

Tono, S., Sularno, M., Mujiono, I., \& Triyanto, A. (1998). Ibadah dan Akhlak Dalam Islam. Yogyakarta: UII Press.

Yusuf, A. M. (1982). Pengantar Ilmu Pendidikan. Jakarta: Ghalia Indonesia. 